\title{
歯肉炎症発症過程におけるへパリチナーゼの役割
}

\author{
村上 純一 \\ 朝日大学歯学部歯周病学講座 \\ (指導 : 岩山幸雄教授) \\ (平成元年 3 月 16 日受付)
}

\section{The Role of Heparitinase in the Initial Stage of Gingival Inflammation}

\author{
Jyunichi MURAKAMI
}

Department of Periodontology, Asahi University, School of Dentisitry

(Director : Prof. Yukio IWAYAMA)

\begin{abstract}
For the purpose of elucidating the effect of heparitinase in gingival tissue, paper strips were inserted in the gingival sulcus of a dog and were treated with heparitinase (experimental group), an enzyme-free solution (control group) or inactived enzyme (control group) for 20 minutes once a day in order to determine the pathohistological changes in the periodontium after 3,10 and 14 days.
\end{abstract}

No marked difference was noted between the 3-day enzyme-treated group and the control groups, but for the 10-day and 14-day enzyme-treated groups, enlargement of the intercellular epithelium, neutrophil infiltration and inflammatory cellular infiltration, mainly of neutrophils, in the subepithelial connective tissue were observed. Examination of the effect of a tracer, ${ }^{3} \mathrm{H}$-Dextran, on the permeability of the epithelium to heparitinase revealed incorporation of ${ }^{3} \mathrm{H}$-Dextran by the enzyme-treated group at about 2 times as much as that by the control group, and there were more silver particles indicative of ${ }^{3} \mathrm{H}-$ Dextran according to autoradiographic findings. Determination of the intratissue location of bacteriumderived heparitinase by the fluorescent antibody technique revealed fluorescence positivity on the gingival sulcus epithelial side but not on the oral epithelial side, and that it was more frequent in the region of the enlarged intercellular area of the upper layer of the gingival sulcus epithelium.

These results suggest that bacterium-derived heparitinase present in the epithelium of the gingival sulcus of a dog lowered the defense competence peculiar to the epithelium and elevated of the permeabilitiy epithelium to bacterium-produced substances, leading to its involvement in the onset of gingival inflammation by decomposing heparan sulfate, an inter-cellular epithelial matrix.

Key words : Heparitinase, Autoradiography, Gingival inflammation

要旨: 本研究の目的は, 歯肉組織におけるへパリチナーゼの影響を明らかにする目的で, イヌの歯肉溝にペーパー ストリップスを挿入し，そこに実験群としてヘパリチナーゼを，また対照群として酵素を含まない溶液だけのもの， および失活酵素を用い，毎日 1 回，20 分間浸み込ませ，3，10,14 日後の歯周組織の変化を病理組織学的に検討した。 その結果, 酵素塗布 3 月群と対照群との閒に著明な差け認められなかったが, 酵素塗布 10 日群枕よび 14 日群に执 て, 上皮閒隙の拡大と好中球の浸潤ならびに，上皮下結合組織における好中球を中心とした炎症性細胞の浸潤が認め られた。さらにトレーサーとして ${ }^{3} \mathrm{H}-$ Dextran を使用しへパリチナーゼの上皮透過性に対する影響を調べた結果，酵

本論文の要旨は第 31 回春季日本歯周病学会総会 (1988 年 4 月 14 日) および第 62 回岐阜歯科学会（1988 年 6 月 18 日）において 発表した。 
素塗布群は対照群に比べ, 約 2 倍の ${ }^{3} \mathrm{H}-$ Dextran の取り込みを示した。またオートラジオグラフィーの所見において も対照群に比較して酵素塗布群で ${ }^{3} \mathrm{H}-$ Dextran を示寸銀粒子を明らかに多く認めた。螢光抗体法によって組織内での 細菌由来へパリチナーゼの局在について検討した結果，螢光陽性部位は，歯肉上皮において歯肉溝上皮側のみに存在 し, 口腔上皮側では認められなかった。さらにその存在部は歯肉溝上皮上層部の細胞間隙の拡大した部位に多く認め られた。

以上の結果より，細菌由来へパリチナーゼは，イヌ歯肉溝上皮に存在し，上皮細胞間マトリックスであるヘパラン 硫酸を分解することによって，上皮本来の防衛能を低下させ，細菌産生物質の上皮透過性を高め，歯肉炎症発症に関 係することが示唆された。

索引用語 : ヘパリチナーゼ, オートラジオグラフィー, 歯肉炎症

\section{緒言}

上皮細胞間マトリックスの 1 つであるへパラン硫 酸 は，コアー蛋白と結合したプロテオグリカンとして，細 胞の plasma membrane ${ }^{1 \sim 3)}$ および basement membrane ${ }^{4 \sim 6)}$ に存在し, 単に生体諸組織の細胞間隙を埋め て支持組織として働くのみならず, 細胞接着 ${ }^{7 \sim 10)}$ や細胞 増殖 ${ }^{11 \sim 13)}$ など, 生体において多彩な機能をになってい る。近年, Bartold ら ${ }^{14)}$ おび白木 ${ }^{15)}$ は, 歯肉上皮と上 皮下結合組織を分離することにより，歯肉上皮における 主要グリコサミノグリカンがヒアルロン酸とヘパラン硫 酸であることを報告した。

一般に歯肉炎症の発症機構の一考察として, 細菌由来 の酵素により上皮細胞間マトリックスが破壞され，その 結果外来侵襲物質の組織内侵入が容易になり，それと共 に歯肉炎症が進展すると考えられている。

上皮を直接障害する酵素として，これまで蛋白を分解 するプロテアーゼ(6 19), 主要グリコサミノグリカンであ るヒアルロン酸を分解するヒアルロニダーゼ ${ }^{20 ~ 26) ~ か ゙ ~}$ 究され, それらが組織破壊に関与すると報告されてき た。しかしヒアルロン酸と共に歯肉上皮の主要グリコサ ミノグリカンであるヘパラン硫酸を分解する酵素の生体 での役割については, 腎臟の糸球体の basement membrane をハハララン硫酸分解酵素处理すると, ferritin ${ }^{27)}$ および alubumin ${ }^{28)}$ を透過させるという報告があるが， 歯肉におけるへパリチナーゼと歯肉炎症との関係につい ての研究は現在のところ報告されていない。

本研究は，歯肉組織に対するへパリチナーゼの影響を 明らかにすることを目的として, (1)へパリチナーゼ叙布 による歯肉組織の変化 (2) ヘパリチナーゼの上皮透過性 への影響 (3) 螢光抗体法による組織内でのへパリチナー ゼの局在について検討した。
実験材料と方法

\section{1. ヘパリチナーゼ塗布による歯肉組織の変化}

実験動物として成犬 3 頭を使用し，健常歯肉を獲得す るために約 1 力月間, 週 2 回のスケーリングとクロルヘ キシジンによる洗浄を行なった。

酵素の調整は Flavobacterium heparinum から抽出 された生化学工業社製へパリチナーゼ標品（至適 $\mathrm{pH}$ 7.0 , 至適温度 $43^{\circ} \mathrm{C}, 37^{\circ} \mathrm{C}$ で $80 \%$ 以上の酵素活性) ${ }^{29,30)}$ 0.3 unit $0.1 \mathrm{M}$ 酢酸ナトリウム $180 \mu l, 0.01 \mathrm{M}$ 酢酸 カルシウム $20 \mu l$ に溶解した。この濃度は, Gaffar ら ${ }^{22)}$ がヒアルロニダーゼの実験で使用した濃度を参考に決定 した。対照群としては, 酵素を含まない溶液だけのもの, および $56^{\circ} \mathrm{C}, 5$ 分間熱変性することで失活した酵素を含 む溶液を用いた。

いずれも簡易防湿下で，唾液，舌および㚘を排除し乾 燥後, イヌ歯肉溝に $2 \times 3 \mathrm{~mm}$ のペーパーストリップス を歯肉を損傷しないように注意深く歯肉溝に挿入し, マ イクロピペットにてストリップスに $2 \mu l$ 浸み込ませ, 10 分間放置後再度塗布し，再び 10 分間放置した。なお 塗布回数によって, 1 頭のイヌで 3 日間塗布群，10 日間 塗布群, 14 日間塗布群の 3 群を設定した。

実験終了後それぞれの歯肉を切除し，直ちに $95 \%$ エ夕ノ・ルで 2 口間固定した後 $4 \mu \mathrm{m}$ のパラフィン切片 を作製し，ヘマトキシリンーエオジン（HE）重染色を行 ない検鏡した。臨床的評価はペリオトロン值を用いた。 すなわち煩側中央部を被験部位として, 簡易防湿, 乾燥 後, 歯肉溝に刺激を与えないように注意深くペーパース トリップスを挿入し，30 秒間静置した後これを廃育し， 2 度目のペーパーストリップスに浸透した 30 秒間の滲 出液量をペリオトロン® (Harco Electric Co. Canada) にて計測することにより得た。 


\section{2. ヘパリチナーゼの上皮透過性への影響}

ヘパリチナーゼ塗布実験と同様の方法で，同一イヌに 酵素狳布群と醳素を含まない溶液のみ塗布する対照群を 設定し, 10 日間塗布した。透過性実験のトレーサーとし て Alfano ら ${ }^{31}$ ) の方法を改変して, ${ }^{3} \mathrm{H}-$ Dextran (分子量: $70,000) 9.25 \mathrm{MBq}(250 \mu \mathrm{ci})$ ⿸ PBS $250 \mu l$ (pH 7.2) に溶解し使用した。

トレーサーの塗布は, ヘパリチナーゼ塗布終了後の 11 日目, ペントバルビタール (ピットマンムーア社, 米国) $0.4 \mathrm{~m} l / \mathrm{kg}$, 上肢静脈内注射による全身麻酔下で左右の開 口器を装着, 重液, 舌および煩を排除し, 酵素塗布実験 と同様 $2 \times 3 \mathrm{~mm}$ のペーパーストリップスを歯肉を損賃 しないように注意深く挿入して, マイクロピペットにて ${ }^{3} \mathrm{H}$-Dextran $2 \mu l[74 \mathrm{KBq}(2 \mu \mathrm{ci})]$ を 30 分毎にストリ ップスにしみ込ませた。なお血中への ${ }^{3} \mathrm{H}-$ Dextran の移 行を調べるため, 15 分毎に静脈より血液を採取し，その $20 \mu l$ ずつをアロカ社製 ASC-113 型自動試料燃焼装置 にて燃焼させアロカ社製 LSC-903 SP 型液体シンチレー ションカウンターにて RI 量を測定した。 4 時間後, 血 中への ${ }^{3} \mathrm{H}-$ Dextran の移行を確認した後屠殺, $0^{\circ} \mathrm{C}$ で組 織の反応を停止させ, 歯肉を切除, PBS ( $\mathrm{pH} 7.2)$ で 3 回洗浄，切片をメスにて半分に分割，一方をオートラジ オグラフィーによる検鏡用に，片方を自動試料然焼装置 で燃焼させ，液体シンチレーションカウンターにて RI 量を測定した。

液体シンチレーションカウンターによる RI 量の測定 は, 歯肉採取後直ちに 3 回洗浄, 万紙にて余剩の水分を 吸い取り湿重量を測定, $-70^{\circ} \mathrm{C}$ で凍結保存した。一週間 後解凍し, PBS (pH 7.2) で再度洗浄, $1 \mathrm{~N} \mathrm{NaOH} 2 \mathrm{~m} l$ でホモジネート, Lowry 法32)により蛋白量を測定，最初 のホモジネートから $100 \mu l$ を自動試料燃焼装置により 燃燒させ, RI 量を液体シンチレーションカウンターにて 測定した。オートラジオグラフィーの処理は，試料採取 後直ちにカルノワ固定を行ない, Bennett ら ${ }^{33)}$ のグリコ ールメタクリレート (GMA) 樹脂（日新 $\mathrm{EM}$, 東京) 包 埋の方法を一部改変して行なった。すなわち $80 \% \mathrm{GMA}$ 10 分間, $90 \%$ GMA 10 分間, $100 \%$ GMA 2 日間, GMAmixture 1 日冷蔵庫内に保存後, $60^{\circ} \mathrm{C}$ で一晚熱重合させ 包埋した。包埋後, $2 \mu \mathrm{m}$ の GMA 樹脂切片を作製, 以 後常法に従い，オートラジオグラフィー用乳剂サクラ NR-M 2 (1.5 倍希釈) を, dipping 法により標本に密着 させ，乾燥後 4 週間露出 $\left(4^{\circ} \mathrm{C}\right)$ した。そして露出，現 像, 定着の後に, サリー染色 ${ }^{33)}$ を施し, 光学顕微鏡下に て観察した。

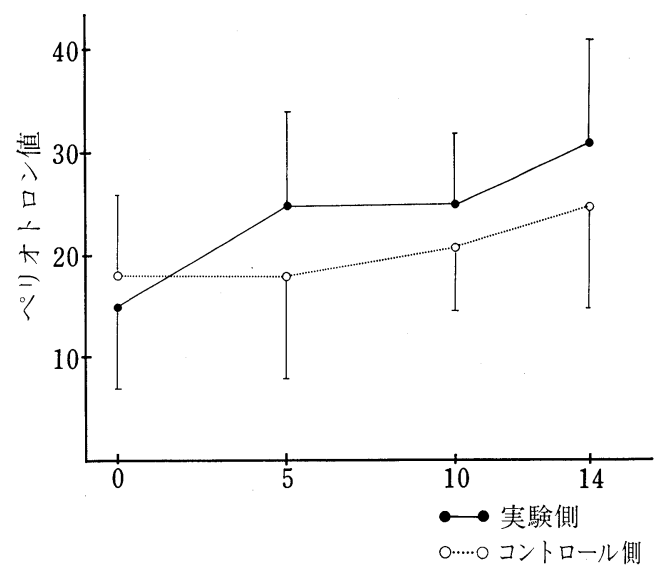

図 1 酵素塗布によるペリオトロン值の変動

3. イヌ歯肉組織におけるヘパリチナーゼの螢光抗体 法による局在

被験材料として，スケーリングなど健常歯肉を獲得す る処置をしていない雑種成犬を使用した。歯肉切除後直 ちに $95 \%$ エタノールで 2 日間にわたり固定，パラフィ ン包埋， $4 \mu \mathrm{m}$ の連続切片を作製して螢光抗体法および HE 染色にて観察した。酵素の調整は, 竹内ら ${ }^{23 ~ 25)} の$ 方 法に準じ，免疫原として塗布実験に使用した酵素と同じ $く$, Flavobacterium heparinum から抽出した生化学工業 社製ヘパリチナーゼ標品を, $50 \mathrm{unit} / \mathrm{m} l$ （蛋白量として $0.02 \mathrm{mg} / \mathrm{ml}$ ) の生食懸濁液とし，等 量の incomplete adjuvant を混合して，その $1 \mathrm{~m} l$ ずつを体重 $2,500 \mathrm{~g}$ 程 度の家鬼の後肢に週 1 回の割合で，4回筋肉内注射を実 施した。

最終注射より 1 週間後, 寒天ゲル内沈降反応により抗 体価の上昇を確認した後に, 頸動脈切断により全採血し 抗血清を得た。それぞれの抗血清から過飽和硫安塩析法 によって crude globulin を抽出し各々の蛋白量にみあ った量の FITCを 10 時間にわたって標識した後, DEAE cellulose column chromatography によって非特異的因 子を除去した。また，予め未標識抗体で反応させ標識抗 体で染色する阻止試験にて, 染色後の螢光陽性所見が特 異的であることを確認した。

\section{結 果}

\section{1. ヘパリチナーゼ塗布による歯肉組織の変化}

イヌ歯肉溝にヘパリチナーゼを反復塗布し，臨床的評 価としてペリオトロン值による歯肉溝滲出液量, ならび に組織学的な変化を検討した。その結果，ペリオトロン 


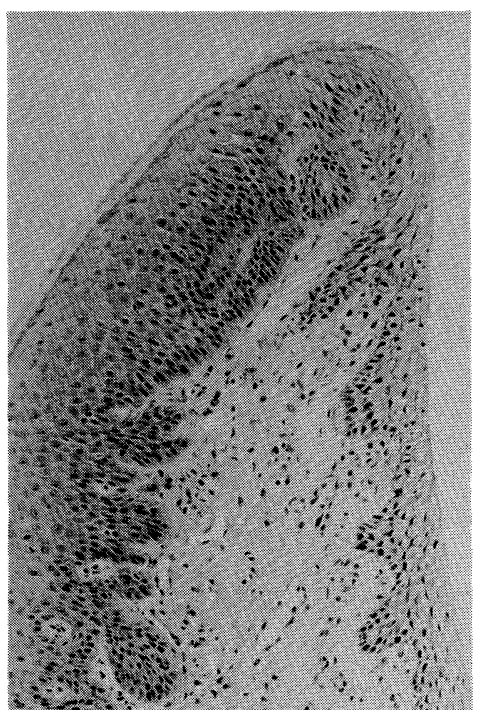

図 2 酵素塗布 3 日目, 炎症性細胞は 少なく, ほぼ正常な歯周組織を 示している。 $\mathrm{HE}$ 染色, $\times 50$

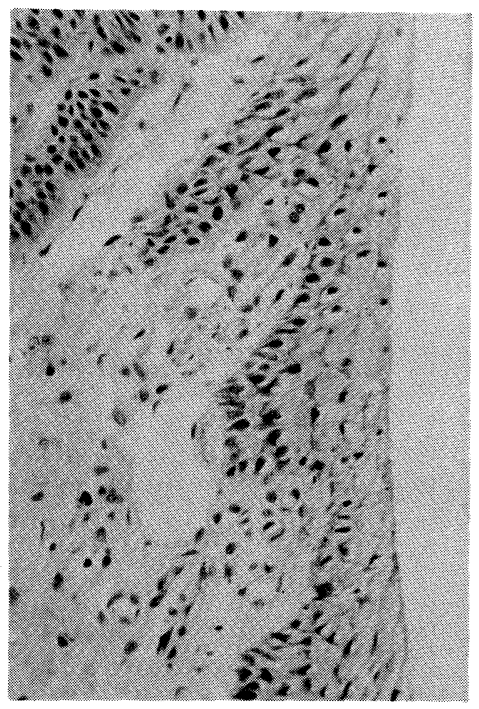

図 3 図 2 の歯肉溝上皮側の拡大像 $\mathrm{HE}$ 染色, $\times 100$

值は, 塗布開始 5 日目以降, 対照群に比較し実験群の方 が高い傾向を示した（図 1)。なお，肉眼的な炎症の臨床 所見については, 対照群と実験群の間に著明な差は認め られなかった。組織学的な変化を検討した結果, 酵素塗 布 3 日群 (図 2,3) と対照群 (図 4,5) との間に著明な 炎症性変化は認められなかったが, 酵素塗布 10 日群 (図 6，7）では，対照群（図 8，9）に比へ，上皮下結合組織

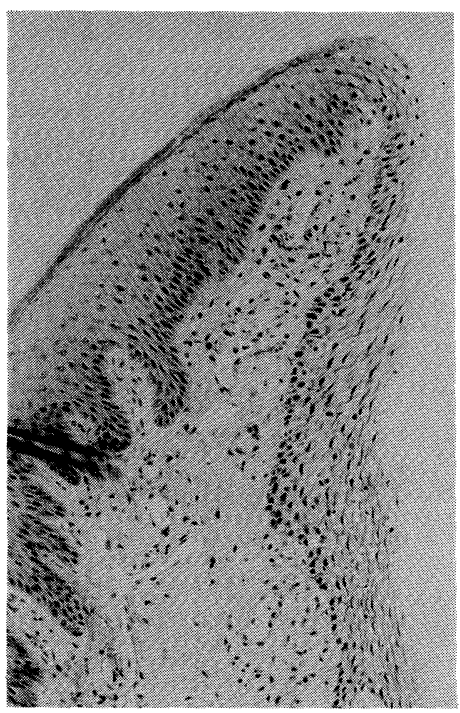

図 43 日目の対照群, 歯肉溝上 皮のわずかな剝雑が認めら れるが炎症性細胞は少な く，ほぼ正常な歯周組織を 示している。

$\mathrm{HE}$ 染色, $\times 50$

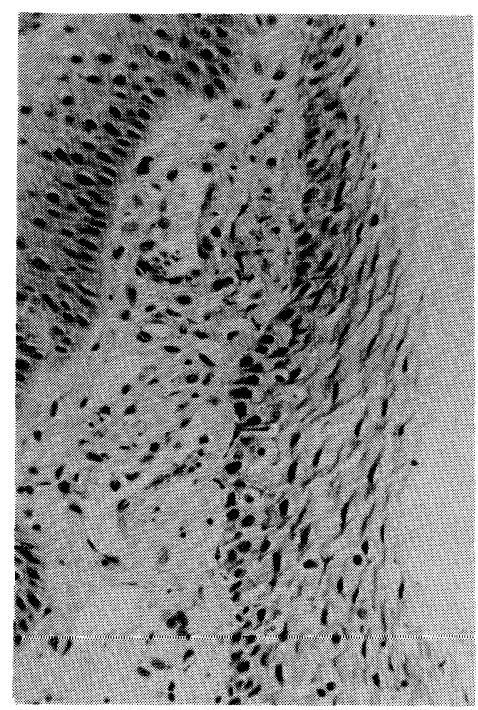

図 5 図 3 の歯肉溝上皮側の拡大像 $\mathrm{HE}$ 染色， $\times 100$

における多数の好中球，リンパ球ならびに単球の浸潤を 認めた。また酵素塗布 14 日群（図 10，11）では，10日 群同様に対照群 (図 12,13) に比較して上皮細胞の萎縮, 上皮間隙の拡大が著しく, その拡大部への好中球の侵入, 上皮下結合組織への好中球，リンパ球および単球の浸潤 


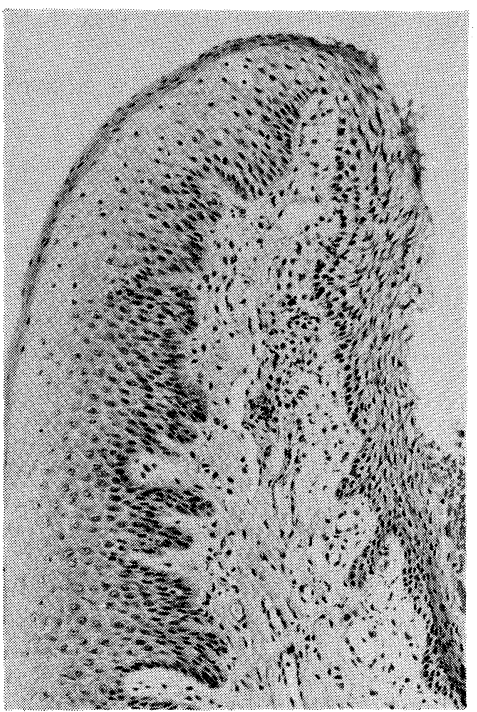

図 6 酵素塗布 10 日目, 歯肉溝上皮 の剝雑, 多数の炎症性細胞浸潤 を認める。HE 染色, $\times 50$

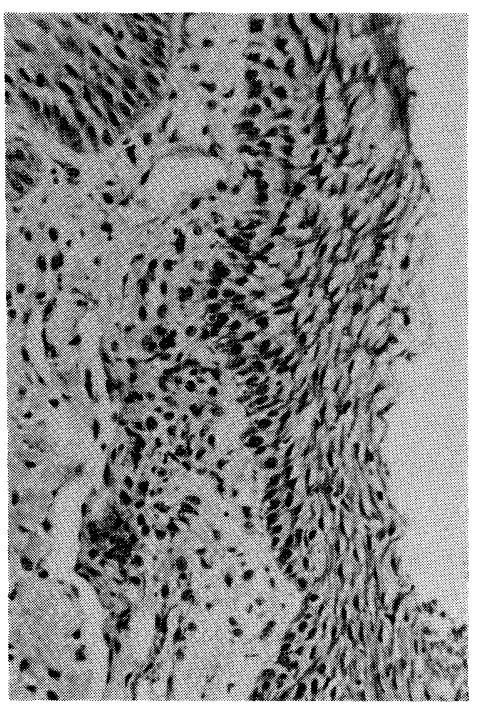

図 7 図 6 の歯肉溝上皮側の拡大像 HE 染色, $\times 100$

が認められた。また失活酵素を塗布した 14 日群におい ては，対照群と同様，著明な炎症性変化は認められなか った（図 14,15)。

\section{2. ヘパリチナーゼの上皮透過性への影響}

イヌ歯肉溝に酵素，または対照群として溶液のみを 10 日間反復塗布した後, ${ }^{3} \mathrm{H}$-Dextran をトレーサーとして 塗布し，ヘパリチナーゼの上皮透過性への影響を調べ

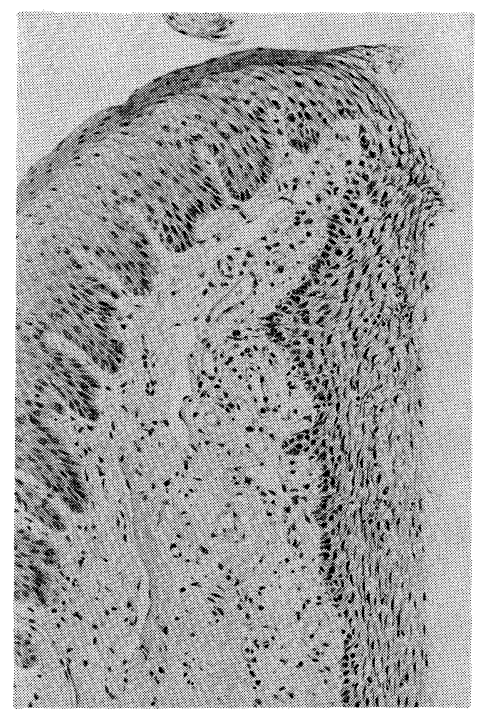

図810日目の対照群, 炎症性細胞は 少なく, ほぼ正常な歯周組織を 示す。HE 染色, $\times 50$

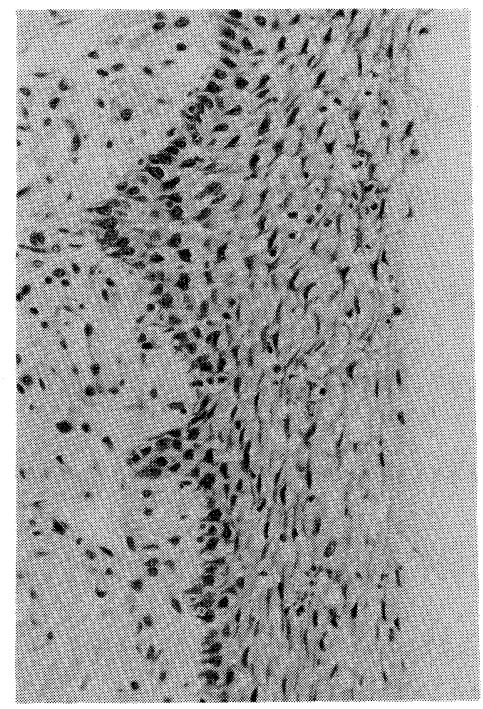

図 9 図 8 の歯肉溝上皮側の拡大像 $\mathrm{HE}$ 染色, $\times 100$

た。血中への RI の移行を調べるため, 経時的に静脈血 を採血, $20 \mu l$ ずつ燃焼装置にて燃焼させ RI 量を測定し た結果, ${ }^{3} \mathrm{H}$-Dextran が歯肉溝上皮を通過して血中に随 時移行していることが示された（図 16）。歯肉組織への ${ }^{3} \mathrm{H}$-Dextran の取り込みを，歯肉を燃焼させることによ り測定した結果，湿重量あたりおよび蛋白量あたりの取 り込みは，いずれも酵素塗布群は対照群に比べ約 2 倍の 


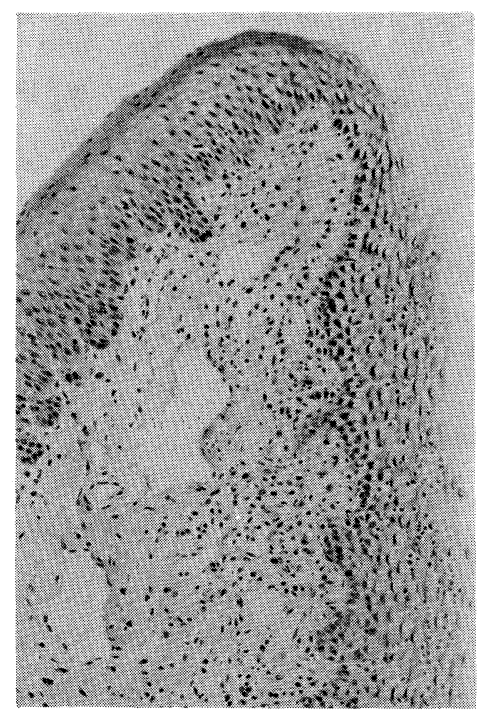

図 10 酵素塗布 14 日目, 歯肉溝上 皮の剝雑ならびに拡大, 上皮 および上皮下結合組織への多 数の炎症性細胞の浸潤を示 す。 $\mathrm{HE}$ 染色, $\times 50$

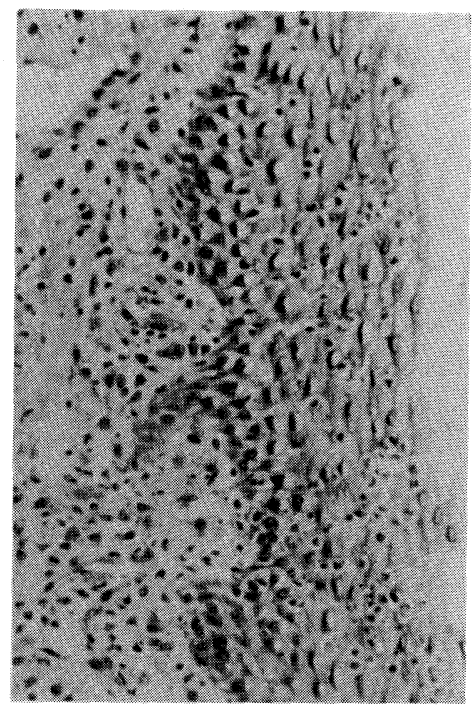

図 11 図 10 の歯肉溝上皮側の拡大像 $\mathrm{HE}$ 染色, $\times 100$

高い值を示した $(\mathrm{P}<0.05)$ (表 1)。

オートラジオグラフィーの所見では, 燃燒実験の結果 同様, 酵素塗布群（図 17,18）と対照群（図 19,20）と の間に ${ }^{3} \mathrm{H}$-Dextran の取り込みの差が認められた。すな わち, 両群とも歯肉溝上皮表層より深部に向かって ${ }^{3} \mathrm{H}-$ Dextranを示す銀粒子を認めたが酵素塗布群において明

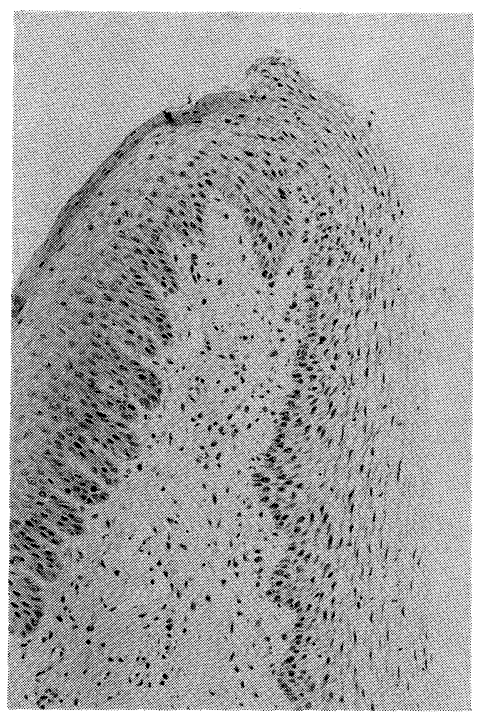

図 1214 日目の対照群, 炎症性細 胞は少なく, ほぼ正常な歯周 組織を示す。HE 染色, $\times 50$

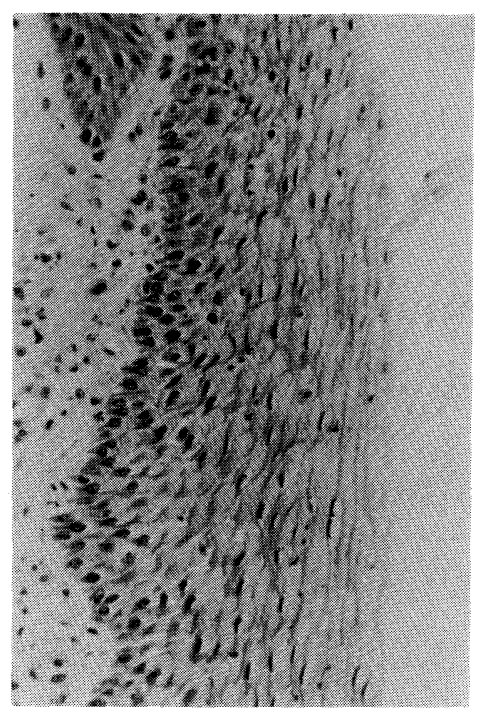

図 13 図 12 の歯肉溝上皮側の拡大像 $\mathrm{HE}$ 染色, $\times 100$

らかに多くの銀粒子を認めた。その分布様式は，直接塗 布した部位，すなわち歯肉溝頂部の上皮に多く歯肉溝の 深い所に少なく，また上皮表層が多く上皮深部および上 皮下結合組織になるに従って少なかった。また銀粒子 は，細胞内および細胞間隙のいずれにも認められたが, 細胞間隙により多く観察され, 細胞間隙を通じて表層よ り徐々に浸透していったものと推察された。対照群にお 


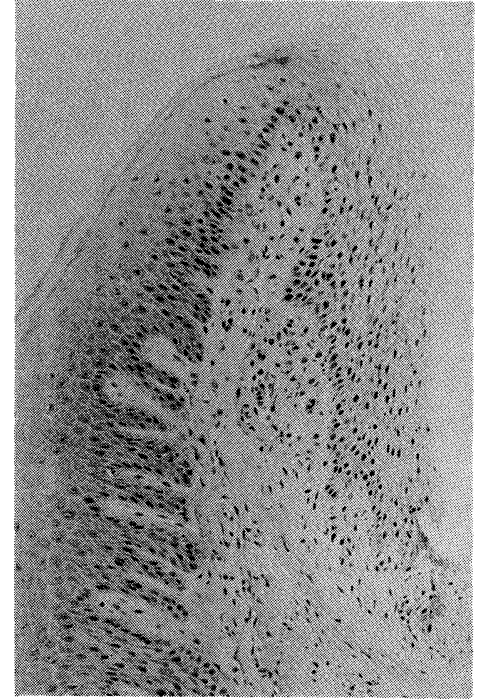

図 14 失活酵素を塗布した 14 日目, 上皮下結合組織にわずかな炎 症性細胞浸潤を認める。 $\mathrm{HE}$ 染色， $\times 50$

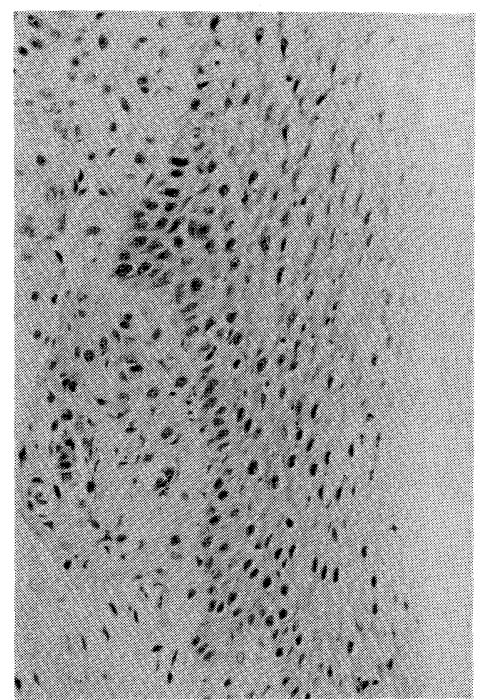

図 15 図 14 の歯肉溝上皮側の拡大像 $\mathrm{HE}$ 染色, $\times 100$

いても銀粒子は，歯肉溝頂部の上皮より侵入し上皮下結 合組織に達していたがその数は, 明かに酵素塗布群に比 較し少なかった。

3. イヌ雬肉組織におけるヘパリチナーゼの螢光抗体 法による局在

最終注射より 1 週間後に採取した血清による寒天ゲル 内沈降反応は, 単一かつシャープな沈降線を呈し抗体価
表 1 歯肉組織における ${ }^{3} \mathrm{H}-$ Dextran の取り込み量

\begin{tabular}{|c|c|}
\hline 対照側 & $*^{*}\left[\begin{array}{c}1931 \pm 1307(\mathrm{dpm} / \mathrm{mg} \text { wet weight }) \\
707 \pm 548(\mathrm{dpm} / \mathrm{mg} \text { protein })\end{array}\right.$ \\
\hline 実験例 & {$\left[\begin{array}{c}L_{4035} \pm 1756(\mathrm{dpm} / \mathrm{mg} \text { wet weight }) \\
1590 \pm 827(\mathrm{dpm} / \mathrm{mg} \text { protein })\end{array}\right.$} \\
\hline & $\begin{array}{l}\text { Mean } \pm \text { S.D. } \quad{ }^{*} \mathrm{P}<0.05 \\
\text { 有意差は } \mathrm{t} \text { 検定により求めた }\end{array}$ \\
\hline
\end{tabular}

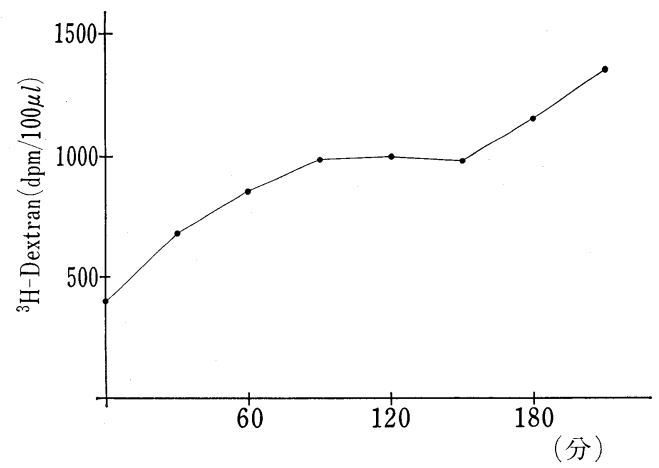

図 16 血中への ${ }^{3} \mathrm{H}-$ Dextran の移行

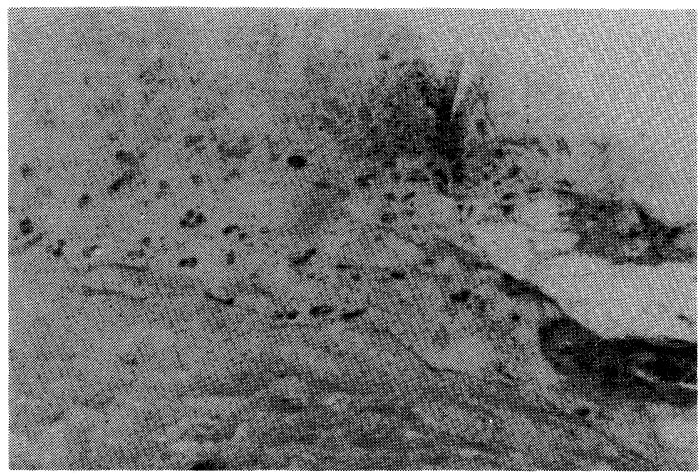

図 17 酵素塗布群における ${ }^{3} \mathrm{H}-$ Dextran 塗布歯肉 の歯肉溝上皮部，上皮表層より深部にかけ 多くの銀粒子が認められる。サリー染色, $\times 200$

が十分に上昇していることが示された（図 21)。また抗 ヘパリチナーゼ抗体で染色した組織切片は，歯肉溝上皮 を中心に強い螢光陽性所見が認められたが (図 22), あ らかじめ未標識抗体で反応させ, 標識抗体で染色した阻 止試験では染色性の明らかな低下が認められた（図 23）。 これらのことより, 得られた螢光反応は, 特異免疫反応 の結果であることが示唆された。

上記のように調整した抗へパリチナーゼ抗体でイヌ歯 


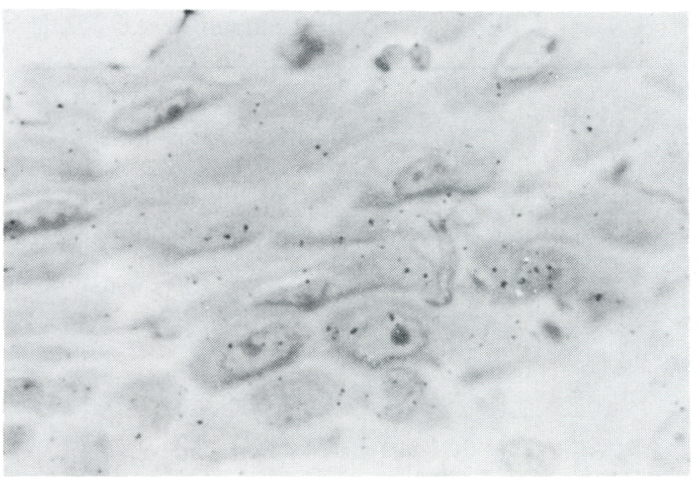

図 18 図 17 の強桩大, 銀粒子は主に細胞間隙に 認められる。サリー染色, $\times 500$

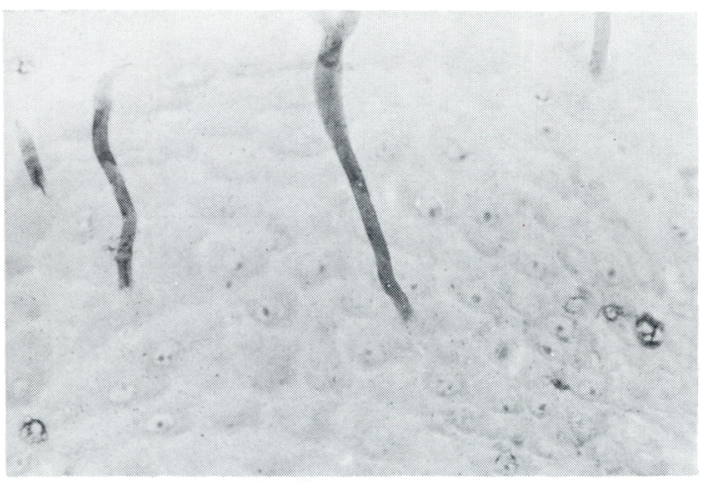

図 19 対照群における ${ }^{3} \mathrm{H}-$ Dextran 塗布歯肉の歯 肉溝上皮部，銀粒子は酵素塗布群（図 17） に比べ少ない。サリー染色， ×200

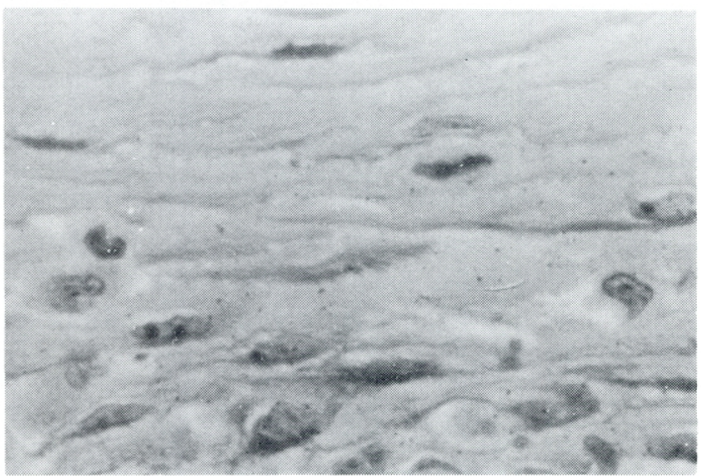

図 20 図 19 の強抎大, 銀粒子は酵素塗布群に比 ベ少ない。サリー染色， $\times 500$

肉組織を染色し，螢光陽性の部位を詳細に検討すると， 上皮においては，歯肉溝上皮に限局して口腔上皮側にお ける溃光陽性例は認められなく,また歯肉溝上皮の表層 から中間層にかけて強い螢光を示し，深部になるにした

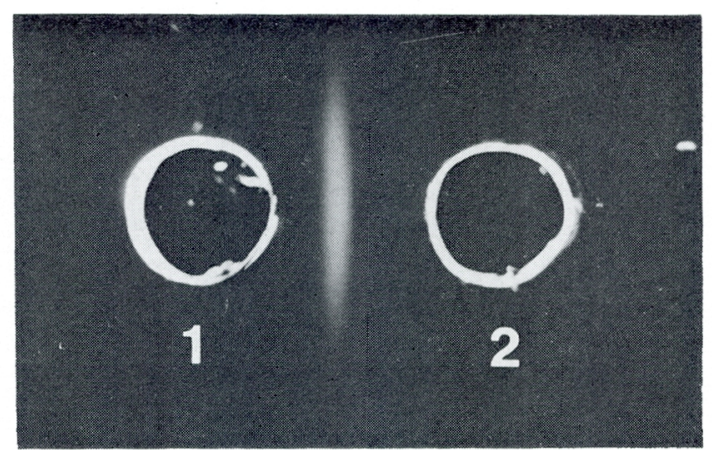

図 21 寒天ゲル内沈降反応

(1) ヘパリチナーゼ

(2) 抗ヘパリチナーゼ血清

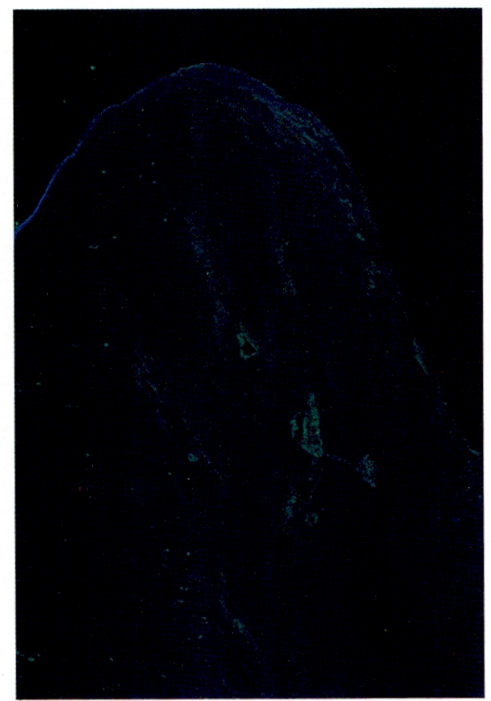

図 22 FITC 標識抗へパリチナーゼ 抗体による䖝光染色, 歯肉溝 上皮に䖝光陽性所見が認めら れる。 $\times 50$

がって弱くなる傾向があった。そして上皮下結合組織に おいては，末梢血管において強い螢光陽性を示した（図 24)。強拡大の所見において, 上皮における螢光陽性部位 を, $\mathrm{HE}$ 所見と対比すると, 上皮の萎縮, 上皮閒隙の離 開，好中球を中心とした炎症性細胞浸潤が多い傾向を示 した(図 25,26)。

考察

ヘパリチナーゼをイヌ歯肉溝に反復塗布し組織学的な 変化を検討した結果，3 日間塗布群では対照群との間に 


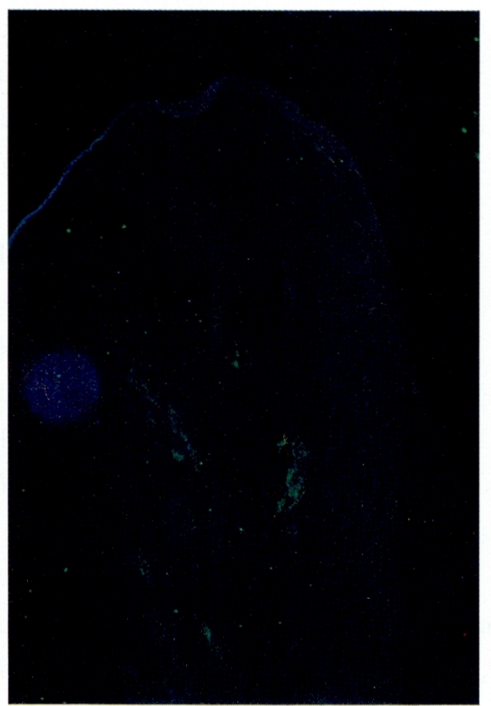

図 23 図 22 の歯肉を未標識抗体で 反応させ標識抗体で染色した 阻止試験, 図 22 に存在した 歯肉溝上皮での螢光陽性所見 が消失している。×50

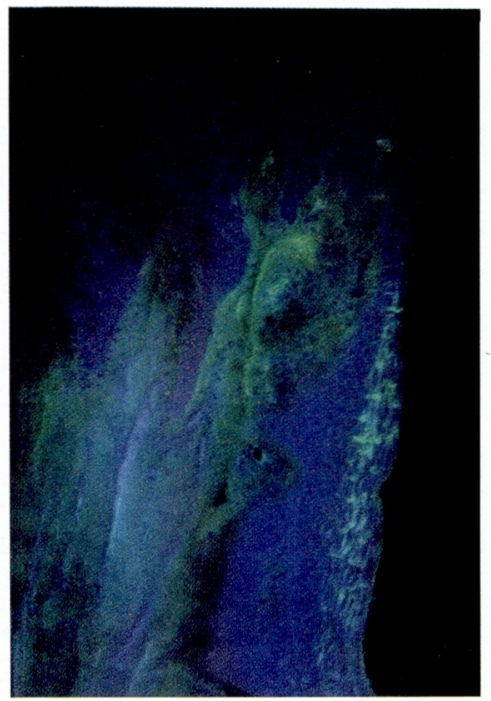

図 24 FITC 標識抗へパリチナーゼ 抗体染色，歯肉溝上皮部に戈 いて強い螢光陽性所見を認め る，口腔上皮側には認められ ない。 $\times 50$

明かな差は認められなかったが，10 日間および 14 日間 塗布群での組織所見は, 上皮細胞の萎縮, 上皮閒隙の拡 大, さらにその㹡大部への好中球の侵入, また上皮下結

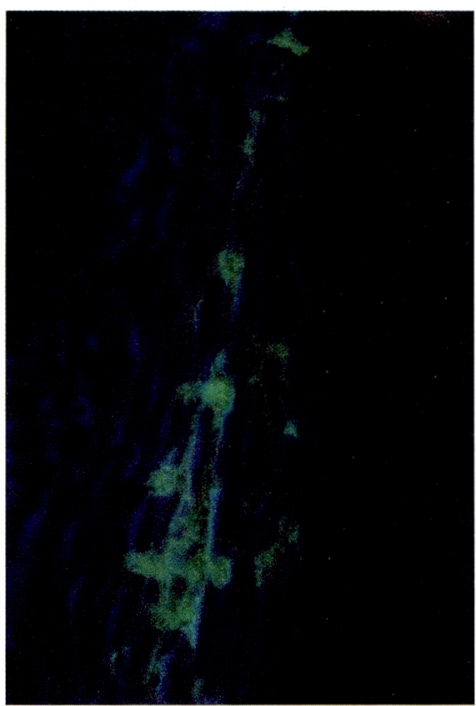

図 25 図 24 の歯肉溝上皮部の強抎 大，螢光は細胞間陌に認めら れ細胞内はほとんど認められ ない。 $\times 200$

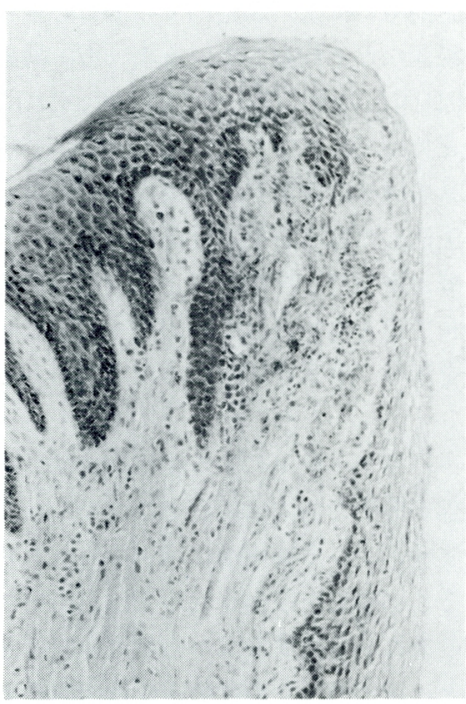

図 26 図 24 の歯肉の $\mathrm{HE}$ 染色, 多 数の炎症性細胞の浸潤上上皮 細胞間隙の桩大が認められ る。 $\times 50$

合組織への好中球, リンパ球および単球の浸潤ならびに 末梢血管の若干の増加が認められた。

これらのへパリチナーゼ塗布による組織変化は, 過 去に行なわれた，プロテアーゼ16 19)，ヒアルロニダー ゼ20 26)の塗布実験での結果と類似していた。すなわち， 
萩原 ${ }^{16)}$, 和泉 ${ }^{17)}$ は, ヒト白血球より抽出したプロテアー ゼを家鬼の歯肉溝に滴下すると, 歯肉溝上皮は, 炎症性 変化や潰瘍を引き起こしたと報告している。また本多18) は, 細菌性プロテアーゼを歯肉切除したラット歯肉に塗 布し，歯周破壊と処置後の治痖の遅延を報告した。小

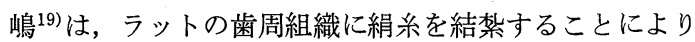
引き起こした炎症が, 細菌性プロテアーゼ滴下によりさ らに悪化，進展することを報告している。

ヒアルロニダーゼについては, Schultz-Haudt ら ${ }^{34) か ゙, ~}$ 1955 年歯肉に初好て作用させ, 上皮細胞間隙の挔大, 血管の拡張, そして結合組織諸細胞の空胞化などが生じ ると報告して以来，多くの研究がなされて来た。Stallad $ら^{20)}$ は, squirrel monkey の歯肉溝上皮にヒアルロニダ 一ゼとコラゲナーゼの混合物を作用させた後, ${ }^{3} \mathrm{H}-\mathrm{Thy}$ midine を注入しオートラジオグラフィーで観察した結 果, 歯肉溝上皮の細胞分裂率が増加したと報告し, 伊集 院ら ${ }^{26)}$ は, ラット臼歯部歯肉溝にヒアルロニダーゼを塗 布し junctional epithelium (JE) に起こる超微形態学 的変化を観察した結果, JE 細胞間の desmosome の数の 減少, 細胞間隙の拡大, 細胞内での著しい空胞の増加, 好中球の浸潤などを観察している。一方，酵素など異種 蛋白を 14 日間も局所に塗布することは, Arthus 型35)炎 症反応など免疫反応による組織障害, およびペーパース トリップスの機械的刺激による炎症なども考えられる。

しかし失活した酵素を塗布した群および溶液のみ塗布 した群と酵素塗布群とを比べると, 失活した酵素狳布群 でわずかに炎症を認めたものの明らかに酵素塗布群で強 、炎症像を示し，酵素作用による反応である事が示唆さ れた。

また，ヘパリチナーゼによる組織障害は，特に歯肉溝 上皮の頂部が著明で歯肉溝底部では少なかった。この結 果は，本実験において歯肉溝にペーパーストリップスを 㨂入し，そこに酵素を浸透させる方法を用いたが，歯肉 溝滲出液の流れが歯肉溝底部から歯冠方向に向かう事を 考虑すると, 滲出液のために酵素の歯肉溝底までの到達 が妨げられたからと考えられる。

ペリオトロン值の経時的変化において, 実験スタート 時に炎症の程度が低いと思われる側を，実験側に選んだ にもかかわらず, 対照群に比べ組織学的所見同様高い值 を示した。なお対照群においても経時的にペリオトロン 值が高くなる傾向を示したが，これはストリップス挿入 による刺激，あるいは口腔清掃を中止したために沈着し たプラークによるものと考えられるが，いずれにしても 酵素作用群が高くなる傾向を示した。
以上の組織変化およびこれに伴う臨床的変化はへパリ チナーゼ自体の作用，あるいはヘパリチナーゼにより細 胞間マトリックスが障害され，上皮本来の防衛能が低下 し，プラーク中の細菌産生物質の上皮通過性が高まった 結果，あるいは両者によるものと推察された。

この点をトレーサーによる上皮透過性の実験によって さらに詳細に検討した。透過性の実験は,これまで色々な 種類のトレーサー22,36 38) が使用されてきた。酵素の透過 性への影響を調べた実験では, Gaffar ら ${ }^{22) か ゙, ~ ヒ ア ル ロ ニ ~}$ ダーゼをラット歯肉に作用させ Streptococcal Polysaccharideの上皮透過性が充進することを螢光抗体法によ る免疫病理学的手法で証明した。田中ら ${ }^{38}$ は, ラット歯 肉にヒアルロニダーゼを作用させその後, cationized ferritin と microperoxidase をトレーサーとして歯肉に 塗布し，電顕的に透過性を検討したが，好中球の遊走以 外何ら歯肉に影響しなかったと報告している。しかしこ れらの物質は正常な歯肉溝上皮では，ほとんど通過しな いので微妙な変化は捉えにくい。したがって著者は， Alfano ら ${ }^{311}$ が口腔粘膜上皮に打ける basement membrane のバリヤーとしての機能を調べるのに使用し，歯 肉上皮を若干通過するけれどもほとんどは，上皮および basement membrane で阻害されると考えられる ${ }^{3} \mathrm{H}-$ Dextran (M.W. 70,000)を使用した。また Dextran が水溶性であることを考慮に入れ，燃焼による RI 量の 測定と, Alfano ら ${ }^{31)}$ の方法を改変しオートラジオグラ フィーによる観察の両方によって, ${ }^{3} \mathrm{H}$-Dextran の歯肉 溝上皮への透過性を調べた。 ${ }^{3} \mathrm{H}$-Dextran 塗布後, 静脈 より得た血中の RI 量は, 経時的に増加した。この血中 への RI の移行は, 歯肉溝上皮より随時 ${ }^{3} \mathrm{H}-$ Dextran が 浸透し上皮下結合組織の未梢血管を通じ血中へ移行した ものと推察される。

茵肉組織を焼燃させることにより取り込まれた RI 量 の測定の結果, 醳素塗布群は対照群に比べ約 2 倍の ${ }^{3} \mathrm{H}-$ Dextran の取り込みを示した $(\mathrm{P}<0.05)$ 。

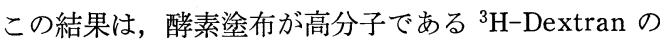
上皮通過性を六進させ得ることを示唆しているが，上皮 組織と結合組織の両者を含む歯肉での結果であるため, ${ }^{3} \mathrm{H}-$ Dextran の組織侵入の局在性については不明であ る。このためにオートラジオグラフィーの手法を用いて ${ }^{3} \mathrm{H}$-Dextran の局在性を検討した。その結果，燃焼実験 同様，対照群に比べ酵素塗布群で ${ }^{3} \mathrm{H}-$ Dextran を示す多 くの銀粒子を歯肉溝上皮および上皮下結合組織に認め, 酵素塗布による ${ }^{3} \mathrm{H}$-Dextran の透過性の六進を確かめる ことができた。オートラジオグラフィーによる銀粒子の 
分布様式は，当然のごとく塗布した歯肉溝上皮表層で多 く存在し，深部に向からにしたがって少なくなった。ま た, 歯肉溝の頂部付近にのみ認められ, 歯肉溝底部付近 では少なかった。これは, 酵素塗布によって炎症症状が 認められた部位に一致していた。対照群における所見も 含め検討すると，叙布実験の結果同様ペーパーストリッ プスを挿入しそこにトレーサーを浸透させるといった 方法では, 歯肉溝滲出液のため歯肉溝の深部までトレー サーが到達しなかったと考えられ，今後酵素およびトレ 一サーをいかに深部まで到達させるかは検討課題であろ う。

上皮に透過した ${ }^{3} \mathrm{H}-$ Dextran は, 細胞内および細胞間 隙の何れにも観察されたが，細胞間隙に主に認められ， 細胞間隙を通じ表層より徐々に浸透していったのではな いかと考えられる。へパラン硫酸分解酵素が組織の透過 性に与える影響を調べた過去の報告としては, Kanwar ら 27)がトレーサーとして ferritin を使用し，また Rosenzweig ら ${ }^{28)}$ が ${ }^{125}$ I-Bovine Serum Albumin を使用 して, ラットの腎藏の系球体の basement membrane に ヘパラン硫酸分解醭素を作用させると, トレーサーの透 過性が六進すると報告している。Kanwar ら ${ }^{27)}$ は同時に 細菌性ヒアルロニダーゼ，コンドロイチナーゼ $\mathrm{ABC}$ を 用いて同様の実験を行なっているが，この場合トレーサ 一の透過光進が起こらないことを報告している。

基底膜のへパラン硫酸プロテオグリカンは他のプロテ オグリカンと異なり, 物質透過に重要な役割を担ってい ると考えられ興味深い。

今回の実験では他のグリコサミノグリカン分解酵素の 応用は行なっていないが，ヘパラン硫酸分解酵素につい てはこれらの報告と類似した結果であった。以上より， イヌ歯肉溝へのヘパリチナーゼ塗布は, 歯肉上皮の透過 性を亢進させることが示唆された。

ヒトの歯周疾患のほとんどは, 歯肉縁下細菌叢と関連 し, 炎症病変が直接また間接的に惹起される。また, こ の細菌中に炎症病変を引き起こす種々の䤉素を産生する 細菌が存在する事が知られている。たとえば口腔内の七 アルロニダーゼ産生菌としては, Streptococcus mitis ${ }^{39)}$, Streptococcus salivarius ${ }^{40)}$, Bacteroides gingivaliis ${ }^{41)}$, Bacteroides melaninogenicus ${ }^{41)}$, そのほか多くの細菌が 証明されている。ヘパリチナーゼ産生菌に関しては, 中 村ら ${ }^{42}$ 44) が, ヒト歯周炎患者のポケットよりBacteroides heparinolyticus (ATCC 35895) を分離し，奥田ら ${ }^{45}, 46$ ) 本菌がヘパラン硫酸分解能を持つ事を報告している。本 実験は，これら細菌が産生した酵素が，実際にイヌ歯肉
に存在するか否か，また，もし存在するのならばその局 在について明らかにするため, 竹内ら ${ }^{24)}$ が, コンドロイ チナーゼおよびヒアルロニダーゼの存在を, ヒト歯肉で 証明した免疫病理学的手法を用い検討した。螢光抗体法 は，極めてコントラストのよい鮮明な染色像が得られる ことで反応の陽性, 陰性の判定が容易であり, さらに抗 原物質の組織細胞内の局在が, 通常の顕微鏡では観察困 難な大きさであっても, 強い螢光によってその所在が分 かるという利点があり, 比較的簡便な方法として広く使 用されている。

本実験において螢光陽性部は, 上皮において歯肉溝上 皮側のみに限局して認められたが口腔上皮には認められ ず，しかも上皮が萎縮し上皮間隙が拡大した上皮表層部 に観察された。これらの螢光反応は, 組織由来の酵素で ある可能性も否定できない。組織由来のへパリチナーゼ

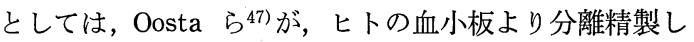
ている。しかし組織由来のものであれば当然口腔上皮に も螢光が認められるはずであり, 歯肉溝上皮表層のしか も細胞間隙の拉大した所に存在するといら所見から, 酵 素は細菌に由来ししかも外部から侵入したと考えて妥当 であろう。一方, 結合組織に認められた螢光反応は, 血 管周囲などが特に高く, 血小板など組織由来の酵素であ る可能性が高いと思われる。

本研究の結果, ヘパリチナーゼは, 歯肉炎症発症の初 期において密接に関係しているものと考えられる。梶 川 ${ }^{48}$ は, イヌ歯肉溝に絹系を結禁することにより惹起し た実験的歯周炎において, 歯肉溝滲出液中のグリコサミ ノグリカンについて検討した結果, 急性炎症期にヒアル ロン酸とヘパラン硫酸が急激に増加したことを報告し た。またプロテオグリカンと結合しているへパラン硫酸 は, 蛋白分解酵素以外にも, ヘパラン硫酸分解酵素によ り, より低分子の蛋白に結合していないヘパラン硫酸単 鎖に分解されることが知られている49,50)。

以上, 細菌の産生したへパラン硫酸分解酵素は, 歯肉 溝上皮に存在し，ヒアルロニダーゼ，プロテアーゼ共々， 歯肉溝上皮細胞間マトリックスを障害することにより, 上皮本来の防衛能を低下させ, 上皮間隙の拡大, 上皮透 過性の充進を引き起こし, その結果外来侵襲物質の組織 内侵入を容易にすることにより, 歯肉炎症を起こすイニ シエーターになる可能性を示唆したが，より詳細に病態 を検討する上で, 多角度から実験を積み重ねて実態を解 明する必要があると考えられる。 


\section{結 論}

イヌ歯肉を対象とし, ヘパリチナーゼによる組織破壊 ならびに上皮透過性への影響について検索した。さらに 螢光抗体法により酵素のイヌ歯肉での存在様式について 検討し, 以下の結論を得た。

（1）イヌ歯肉溝にヘパリチナーゼを反復塗布し組織学 的な変化を検討した結果, 3 日間酵素塗布群では, 著明 な変化は認められなかったが，10日間および 14 日間酵 素塗布群に掠いて, 上皮間隙の泣大と好中球の浸潤なら びに, 上皮下結合組織における好中球を中心とした炎症 性細抱の浸潤が認められた。さらにペリオトロン值の経 時的変動においても, 酵素塗布群は対照群に比較して高 い值を示した。

（2）へパリチナーゼの上专透過性への影響を調べるた め, トレーサーとして ${ }^{3} \mathrm{H}-$ Dextran を使用し, 燃焼実験 およびオートラジオグラフィーによる手法を用いて検討 した結果, 両実験とも対照群に比較して実験群で ${ }^{3} \mathrm{H}-$ Dextranの組織透過性が増加することが認められた。

(3) イヌ歯肉組織でのヘパリチナーゼの局在を螢光抗 体法で調べた結果, 螢光陽性部は歯肉上皮において歯肉 溝上皮側のみに存在し, 口腔上皮側では認められず，ま たその存在部は歯肉溝辺縁の比較的上層部であり, さら に細胞間隙の拡大した所に多く認められた。

以上から, 細菌由来へパリチナーゼは, イヌ歯肉溝上 皮に存在し上皮細胞間マトリックスであるへパラン硫酸 を分解することによって, 上皮本来の防衛能を低下させ, 細菌産生物質の上皮透過性を高め, 歯肉炎症発症に関係 することが示唆された。

\section{謝 辞}

稿を終えるにあたり, 御指導と御校閲を賜った朝日大学歯学 部歯周病学講座 岩山幸雄教授に哚く感謝致します。さらに, 貴重なる御助言と御校閲を頂きました本学病理学講座 竹内 宏 教授, 生化学講座 横田 豊教授ならびに本講座前助教授 勝谷 芳文先生に深く感謝いたします。

また, 研究に際し, 御助力と御鞭撻をいただいた歯周病学講 座 白木雅文助教授をはじめとする教室員の皆様ならびに RI 研 究施設, 山口良三先生に深謝致します。

本研究は一部昭和 61 年度宮田研究奨励金の補助により行なわ れたことを付記する。

\section{文献}

1) Oldberg, Å., Kjellén, L. and Höök, M. : Cellsurface Heparan Sulfate. J. Biol. Chem., 254 : 8505-8510, 1979.

2) Kjellén, L., Oldberg, À. and Höök, M. : Cellsurface Heparan Sulfate. J. Biol. Chem., 255 : 10407-10413, 1980.

3) Klinger, M.M., Margolis, R.U. and Margolis, R.K. : Isolation and Characterization of the Heparan Sulfate Proteoglycans of Brain. J. Biol. Chem., 260 : 4082-4090, 1985.

4) Hayman, E.G., Oldberg, A., Martin, G.R. and Ruoslahti, E. : Codistribution of Heparan Sulfate Proteoglycan, Laminin, and Fibronectin in the Extracellular Matrix of Normal Rat Kidney Cells and Their Coordinate Absence in Transformed cells. J. Cell Biol., 94 : 28-35, 1982.

5) Laurie, G.W., Leblond, C.P. and Martin, G.R. : Localization of Type IV Collagen, Laminin, Heparan Sulfate Proteoglycan, and Fibronectin to the Basal Lamina of Basement Membranes. J. Cell Biol., 95 : 340-344, 1982.

6) Leivo, I. : Basement Membrane-Like Matrix of Teratocarcinoma-derived Endodermal Cells : Presence of Laminin and Heparan Sulfate in the Matrix at Points of Attachment to Cells. J. Histochem. Cytochemy., $31: 35-45,1983$.

7) Culp, L.A., Murray, B.A. and Rollins, B.J. : Fibronectin and Proteoglycans as Determinants of Cell-Substratum Adhesion. J. Supramol. Struct., $11:$ 401-427, 1979.

8) Schubert, D. and LaCorbiere, M. : A Role of Secreted Glycosaminoglycans in Cell-Substratum Adhesion. J. Biol. Chem., 255 : 1156411569, 1980.

9) Schubert, D. and LaCorbiere, M. : The Specificity of Extracellular Glycoprotein Complexes in Mediating Cellular Adhesion. J. Neurosci., $2: 82-89,1982$.

10) Woods, A., Höök, M., Kjéllen, L., Smith, C.G. and Ress, D.A. : Relationship of Heparan Sulfate Proteoglycans to the Cytoskeleton and 
Extracellular Matrix of Cultured Fibroblasts. J. Cell Biol., 99 : 1743-1753, 1984.

11) Culp, L.A., Rollins, B.J., Buniel, J. and Hitri, S. : Two Functionally Distinct Pools of Glycosaminoglycan in the Substrate Adhesion Site of Murine Cells. J. Cell Biol., 79 : 788-801, 1978.

12) Castellot, J.J., Addonizio, M.L., Rosenberg, R. and Karnovsky, M.J. : Cultured Endothelial Cells Produce a Heparinlike Inhibitor of Smooth Muscle Cell Growth. J. Cell Biol., 90 : 372-379, 1981.

13) Ratner, N., Bunge, R.P. and Glaser, L. : A Neuronal Cell Surface Heparan Sulfate Proteoglycan is Required for Dorsal Root Ganglion Neuron Stimulation of Schwann Cell Proliferation. J. Cell Biol., 101 : 744-754, 1985.

14) Bartold, P.M., Wiebkin, O.W. and Thonard, J.C. : Glycosaminoglycans of Human Gingival Epithelium and Connective Tissue. Connect. Tissue Res., 9 : 99-106, 1981.

15）白木雅文：健常イヌ歯肉組織における上皮ならび に上皮下結合組織のグリコサミノグリカンについ て. 月歯周誌, $28: 78.7999,1986$.

16）萩原さつき：ヒト白血球からのライソゾーム酵素 が歯周組織に与える影響について（ウサギにおけ る実馀的研究). 日歯周誌, $21: 392-409,1979$.

17）和泉雄一：ヒト白血球より抽出したライソゾーム 酵素が歯周組織に及ぼす影響について一in vitro ならびに in vivo における実験的研究一. 日歯周 誌, $25:$ 144-159, 1983.

18）本多隆保 : ラットの歯肉の創塲治瘺におよぼす細 菌性プロテアーゼとアロキサン糖尿病の影響. 日 歯周誌, $28: 39-55,1986$.

19）小䲴久雄 : 細菌性プロテアーゼの滴下によるラッ 卜歯周組織つ病理組織学的変化について. 愛院大 歯誌, $25: 79-95,1987$.

20) Stallard, R.E. and Awwa, I.A. : The Effect of Alterations in External Environment on the Dentogingival Junction. J. Dent. Res., 48 : 671-675, 1939.

21) Smith, F.N. and Ramfjord, S.P. : Hyaluronidase Applied to the Gingiva of Rhesus Monkeys. J. Periodontol., 44 : 361-365, 1973.
22) Gaffar, A., Coleman, E.J. and Marcussen, H.W. : Penetration of Dental Plaque Components into Gingiva : Sequential Topical Treatments with Hyaluronidase and Streptococcal Polysaccharide in rats. J. Periodontol., 52 : 197-205, 1981.

23）竹内 宏, 堀 泰典, 金久純也, 佐藤 勝, 並河 勇 : 辺縁性歯周炎の免疫病理学的研究. 第 7 報 歯 周炎と細菌酵素（その 1 ）歯垢中の chondroitinase と hyaluronidase の局在について. 歯基礎誌, $24: 986-992,1982$.

24）竹内 宏, 堀 泰典, 金久純也, 上田雅俊, 谷 明, 佳川宽典 : 辺縁性歯周炎の免疫病理学的研 究. 第 7 報 歯周炎と細菌酵素 (その 2 ) 炎症歯 肉に㧍ける bacterial chondroitinase $\mathrm{ABC}$ と hyarluronidase について. 歯基礎誌, 25 : 437442, 1983.

25）竹内 宏, 堀 泰典, 佐藤 勝, 並河 勇: 辺縁 性歯周炎の免疫病理学的研究. 第 7 報 (その 3 ) chondrotinase および hyaluronidase 産生菌の検 討. 歯基楚誌, $25: 443-447,1983$.

26）伊集院直邦, 高田 隆, 山崎 章, 二階宏昌 : 付 着上皮, 歯小皮, 歯肉の微細構造と歯周疾患. 細 胞, $15: 12-17,1983$.

27) Kanwar, Y.S., Linker, A. and Farquhar, M.G. : Increased Permeabilitiy of the Glomerular Basement Membrane to Ferritin after Removal of Glycosaminoglycans (Heparan Sulfate) by Enzyme Digestion. J. Cell Biol., 86 : 688-693, 1980.

28) Rosenzweig, L.J. and Kanwar, Y.S. : Removal of Sulfated (Heparan Sulfate) or Nonsulfated (Hyaluronic Acid) Glycosaminoglycans Results in Increased Permeability of the Glomerular Basement Membrane to ${ }^{125} \mathrm{I}$-Bovine Serum Albumin. Lab. Invest., 47 : 177-184, 1982.

29) Hovingh, P. and Linker, A. : The Enzymatic Degradation of Heparin and Heparitin Sulfate. III. Purification of a Heparitinase and a Heparinase from Flavobacteria. J. Biol. Chem., 245 : 6170-6175, 1970.

30) Linker, A. and Hovingh, P. : Heparinase and Heparitinase from Flavobacteria. Method in Enzymol., 28 : 902-911, 1972. 
31) Alfano, M.C., Chasens, A.I. and Masi, C.W. : Autoradiographic Study of the Penetration of Radiolabelled Dextrans and Inulin Through Non-Keratinized oral mucosa in vitro. J. Periodont. Res., 12 : 368-377, 1977.

32) Lowry, O.H., Rosebrough, N.J., Farr, A.L. and Randall, R.J. : Protein Measurement with the Folin Phenol Reagent. J. Biol. Chem., 193 : 265-275, 1951.

33) Bennett, H.S., Wyrick, A.D., Lee, S.W. and McNeil, J.H. : Science and Art in Preparing Tissues Embedded in Plastic for Light Microscopy, with Special Reference to Glycol Methacrylate, Glass knives and Simple Stains. Stains Technol., $51:$ 71-97, 1976.

34) Schultz-Haudt, S.D. and Scherp, H.W. : Production of Hyaluronidase and Beta-Glucuronidase by Viridans Streptococci Isolated from Gingival Crevices. J. Dent. Res., 34 : 924-929, 1955.

35）林 秀男, 河野 正, 山本俊輔, 吉永 秀: 炎症 とプロテアーゼ, 村地 孝, 浅田敏雄, 藤田節郎: 蛋白分解酵素と生体防禦. 学会出版センター, 東 京, 99-124, 1979.

36) McDougall, W.A. : Penetratin Pathways of a Topically applied foreign protein into rat gingiva. J. Periodont. Res., 6 : 89-99, 1971.

37) Schwartz, J., Stinson, F.L. and Parker, R.B. : The Passage of Tritiated Bacteria Endotoxin Across Intact Gingival Crevicular Epithelium. J. Periodontol., $43:$ 270-276, 1972.

38）田中輝男, 坂野 彰, 綾坂則夫 : ラット正常歯肉 における付着上皮へのトレーサーとしての Cationized Ferritin と Microperoxidase の浸透性に ついての研究. 歯基礎誌, $30: 1-13,1988$.

39) Nord, C.E. : Purification and Properties of Hyaluronidase from Streptococcus mitis. Odont. Revy., 22 : 125-136, 1971.

40) Rautela, G.S. and Abramson, C. : Crystalliza- tion and Partial Characterization of Staphylococcus aureus Hyaluronate Lyase. Arch. Biochem. Biophys., 158 : 687-694, 1973.

41) Tipler, L.S. and Embery, G. : Glycosaminoglycan-Depolymerizing Enzymes Produced by Anaerobic Bacteria Isolated from the Human Mouth. Archs Oral Biol., 30 : 391-396, 1985.

42）中村 武：口腔内嫌気性 Heparinase 産生菌に関 する研究. 十全医会誌, $78: 509-530,1969$.

43）中村 武, 杉中芳幸, 高添一郎, 奥田克爾 : 口腔 内 Heparinase 産生性 Bacteroides $の$ Endotoxin の生物学的活性. 松本歯学, $2: 12-19,1976$.

44) Nakamura, T., Suginaka, Y. and Takazoe, I. : Heparinase Activity in Lesion of Periodontal Diseases. Bull. Tokyo dent. Coll., 17 : 147-155, 1976.

45）奥田克爾, 塩津二郎, 高添一郎, 中村 武 : Bacteroides Heparinolyticus sp. nov. に関する分類 学的研究. 日細菌誌, $39: 596,1984$.

46) Okuda, K., Kalu, T., Shiuzu, J., Takazoe, I. and Nakamura, T. : Bacteroides Heparinolyticus sp. nov. Isolated from Humans with Periodontitis. Int. J. Syst. Bacteriol., 35 : 438442, 1985.

47) Oosta, G.M., Favreau, L.V., Beeler, D.L. and Rosenberg, R.D. : Purification and Properties of Human Platelet Heparitinase. J. Biol. Chem., 257 : 11249-11255, 1982.

48）梶川 潔 : イヌの実験的歯周炎における歯肉溝滲 出液中のグリコサミノグリカンについて，日歯周 誌, $28: 500-515,1986$.

49) Oohira, A., Wight, T.N. and Bornstein, P. : Sulfated Proteoglycans Synthesized by Vascular Endothelial Cells in Culture. J. Biol. Chem., 258 : 2014-2021, 1983.

50）大平敦彦：細胞表層に存在するへパラン硫酸プロ テオグリカンの構造 と機 能. 代 謝, $21: 9-17$, 1984. 